\title{
The distribution of littoral caprellids (Crustacea: Amphipoda: Caprellidea) along the Pacific coast of continental Chile
}

\author{
La distribución de caprélidos litorales (Crustacea: Amphipoda: Caprellidea) en la \\ costa del Pacífico de Chile continental
}

\section{MARTIN THIEL ${ }^{1 *}$, JOSÉ M. GUERRA-GARCÍA², DOMINGO A. LANCELLOTTI ${ }^{1} \&$ NELSON VÁSQUEZ $^{1}$}

\author{
${ }^{1}$ Facultad de Ciencias del Mar, Universidad Católica del Norte, Larrondo 1281, Coquimbo, Chile; \\ e-mail: thiel@ucn.cl \\ ${ }^{2}$ Laboratorio de Biología Marina, Departamento de Fisiología y Biología Animal, Facultad de Biología, \\ Universidad de Sevilla, Apartado 1095, E-41080, Sevilla, España \\ (*corresponding author)
}

\begin{abstract}
Many littoral caprellid species have a very ample distribution, some having been reported from all over the world. The cosmopolitan distribution of many littoral caprellid species might be facilitated by the fact that they are often associated with fouling communities on floating objects, which have a high potential of far-range dispersal. This dispersal potential may also have implications for the distribution of caprellids on local and regional scales. Herein we examined the distribution of littoral caprellid species on two spatial scales, local (tens of kilometers) and regional (hundreds of kilometers) along the Pacific coast of continental Chile. On the local scale, we studied the caprellid fauna in different habitats (intertidal boulders, subtidal algal and seagrass beds, fouling community on buoys and ropes); on the regional scale we focused only on caprellids associated with the fouling community on buoys and ropes. We found a total of six caprellid species, some of which were very abundant both on the local as well as on the regional scale. On the local scale we found a difference between the three studied habitat types with respect to the assemblage of caprellid species, some of which were found in more than one habitat. The highest species richness and abundance of caprellids was found in the fouling community associated with anchored buoys and ropes. On the regional scale we found very high numbers of caprellids in the fouling community of the northern region ( $\mathrm{n}$ of $30^{\circ} \mathrm{S}$ ), and decreasing abundances and species richness in the central region $\left(30-37^{\circ} \mathrm{S}\right)$. No caprellids were found in the southern region of the study area $\left(37-42^{\circ} \mathrm{S}\right)$. This pattern coincides with the global distribution of littoral caprellid species, which are most abundant and diverse at low latitudes but occur in low abundances and low diversity at high latitudes. Detached buoys that were found a few km off the coast harbored similar caprellid assemblages (including ovigerous females) as anchored buoys, suggesting that buoys and other floating substrata (litter, macroalgae) may facilitate dispersal of caprellids (and other epibiota) along the Pacific coast of Chile. Since artificial and natural floating substrata are also abundant at high latitudes it is inferred that the low diversity of littoral caprellids at high latitudes is not due to lack of dispersal vectors, but rather of other factors.
\end{abstract}

Key words: Crustacea, Amphipoda, Caprellidea, Chile, biogeography.

\section{RESUMEN}

Muchas especies de caprélidos del litoral presentan una amplia distribución, algunas han sido citadas a lo largo de todo el mundo. La distribución cosmopolita de muchas especies de caprélidos podría deberse al hecho de que se asocian frecuentemente a las comunidades "fouling" en objetos flotantes, que presentan una capacidad importante de dispersión a largas distancias. Esta capacidad de dispersión puede tener implicaciones en la distribución de caprélidos a escala local y regional. En este estudio, nosotros examinamos la distribución de las especies de caprélidos litorales en dos escalas espaciales, local (decenas de kilómetros) y regional (cientos de kilómetros), a lo largo de la costa Pacífico de Chile continental. A escala local se estudió la fauna de caprélidos en distintos hábitats (bolones intermareales, praderas de algas y fanerógamas marinas, comunidades "fouling" de boyas y cuerdas); a escala regional el estudio se centró solamente en los caprélidos asociados a boyas y cuerdas. Se encontraron un total de seis especies de caprélidos, algunos de los cuales fueron muy abundantes a escala local y regional. A escala local, existió una diferencia entre los tres tipos de hábitat con respecto a la fauna de caprélidos, algunos de los cuales estuvieron presentes en más de un hábitat. Los valores más altos de riqueza específica y abundancia se encontraron en la comunidad "fouling" asociada a boyas y cuerdas ancladas. A escala regional, los caprélidos fueron más abundantes y diversos en las comunidades "fouling" de la región norte (n de $30^{\circ} \mathrm{S}$ ), mientras que la abundancia y riqueza de especies disminuyeron en la región central $\left(30-37^{\circ} \mathrm{S}\right)$. No se encontraron caprélidos en la región sur del área de estudio $\left(37-42^{\circ} \mathrm{S}\right)$. Este patrón coincide con la distribución global de especies de caprélidos litorales, mostrando los valores más altos de abundancia y riqueza de especies en las bajas latitudes y los valores más bajos en las altas latitudes. Boyas desprendidas desde sus amarras y encontradas a varios km de la costa albergaron asociaciones de caprélidos (incluyendo hembras ovígeras) similares a las de las boyas fijadas, sugiriendo que 
las boyas y otros sustratos flotantes pueden facilitar la dispersión de caprélidos (y otra epifauna) a lo largo de la costa Pacífico de Chile. Teniendo en cuenta que los sustratos flotantes naturales y artificiales son también abundantes en altas latitudes se infiere que la baja diversidad de caprélidos litorales en altas latitudes no se debe a la falta de vectores dispersantes sino a otros factores.

Palabras clave: Crustacea, Amphipoda, Caprellidea, Chile, biogeografía.

\section{INTRODUCTION}

Caprellid amphipods are common members of many littoral habitats, and they are particularly abundant in epibiotic fouling communities. They are very common and diverse on erect bryozoans and hydrozoans and on plant substrata such as macroalgae and seagrasses (McCain 1968). They feed on suspended materials, prey on other organisms, or graze on epibiotic fauna and flora (Caine 1974). Locally, caprellids are important prey for many coastal fish species (Caine 1987, 1989, 1991), and they may be important members of littoral communities.

Many caprellid species have a wide distribution and there are many examples of species that are considered to be cosmopolitans (Takeuchi \& Sawamoto 1998). With their general morphology, caprellids are well adapted to cling to substrata such as algae and hydroids (Takeuchi \& Hirano 1995). Using their last pereiopods they can firmly hold onto branches of algae, bryozoans and hydrozoans. The pleopods, which are used for swimming in other amphipod crustaceans, are reduced in caprellids. Therefore, although caprellids can swim (Caine 1979), they probably are not very efficient swimmers. This, as well as the lack of a planktonic larval stage, suggests that cosmopolitan caprellid species may be distributed passively by clinging to floating materials rather than by active swimming. Floating materials such as macroalgae are easily distributed between distant locations (Ingólfsson 1995, Hobday 2000a) and caprellids and other amphipods are commonly found on this type of substrata (Hobday 2000b). Many caprellid species are also very unselective with respect to their substratum and they colonize a wide variety of different substrata. For example the species $C$. equilibra has been found on algae, seagrasses, bryozoans, bivalves, sponges and other substrata (KrappSchickel 1993). This low selectivity for a wide variety of substrata that have high floating potential suggests that these species might have a wide distribution, particularly in regions where ocean currents transport suspended or floating materials (algae, bryozoans, wood or buoys and other anthropogenic material) over large distances.

Although the abundance and species richness of caprellids in many areas of the world's oceans is still poorly known, Laubitz (1970) pointed out that surface water temperature is an important factor determining the distribution of littoral caprellids along the American coast of the North Pacific. Similar as for other taxa (e.g., corals Fraser \& Currie 1996; molluscans - Roy et al. 1998, 2000), species richness of caprellids decreases gradually towards northern latitudes (Laubitz 1970). Water temperature may affect the distribution of caprellids along the American coast of the South Pacific in a similar way as in the North Pacific since the oceanic regime and in particular the latitudinal variation in water temperatures show similarities between these two regions. It can therefore be expected that diversity of littoral caprellids along the Pacific coast of Chile also decreases towards high latitudes. Nevertheless, on a more local scale, and in particular in bay systems, water circulation leads to intense local mixing (Sobarzo 2002), and the distribution pattern of caprellid amphipods therefore can be expected to be relatively uniform within local bay systems.

In the present study, we examined the composition of the caprellid fauna both on a local and regional scale. The local distribution was examined within a system of bays, i.e., over a scale of tens of $\mathrm{km}$, while the regional distribution of caprellids was examined along a latitudinal gradient at sites separated by hundreds of $\mathrm{km}$. The principal objective of this study was to reveal the species richness of littoral caprellids and their distribution pattern along the Pacific coast of continental Chile. We incorporate data on the caprellid assemblage from detached buoys found a few $\mathrm{km}$ offshore since this information contributes to a better understanding of both the local and regional distribution of caprellids.

\section{MATERIAL AND METHODS}

The local distribution pattern of littoral caprellids was examined in the bay system of Coquimbo, northern-central Chile (Fig. 1). In November/ December 2000, semi-quantitative samples were taken in three different habitats, intertidal boulders, subtidal algal and seagrass beds and fouling communities from buoys and ropes. Preliminary surveys had revealed that caprellid amphipods 


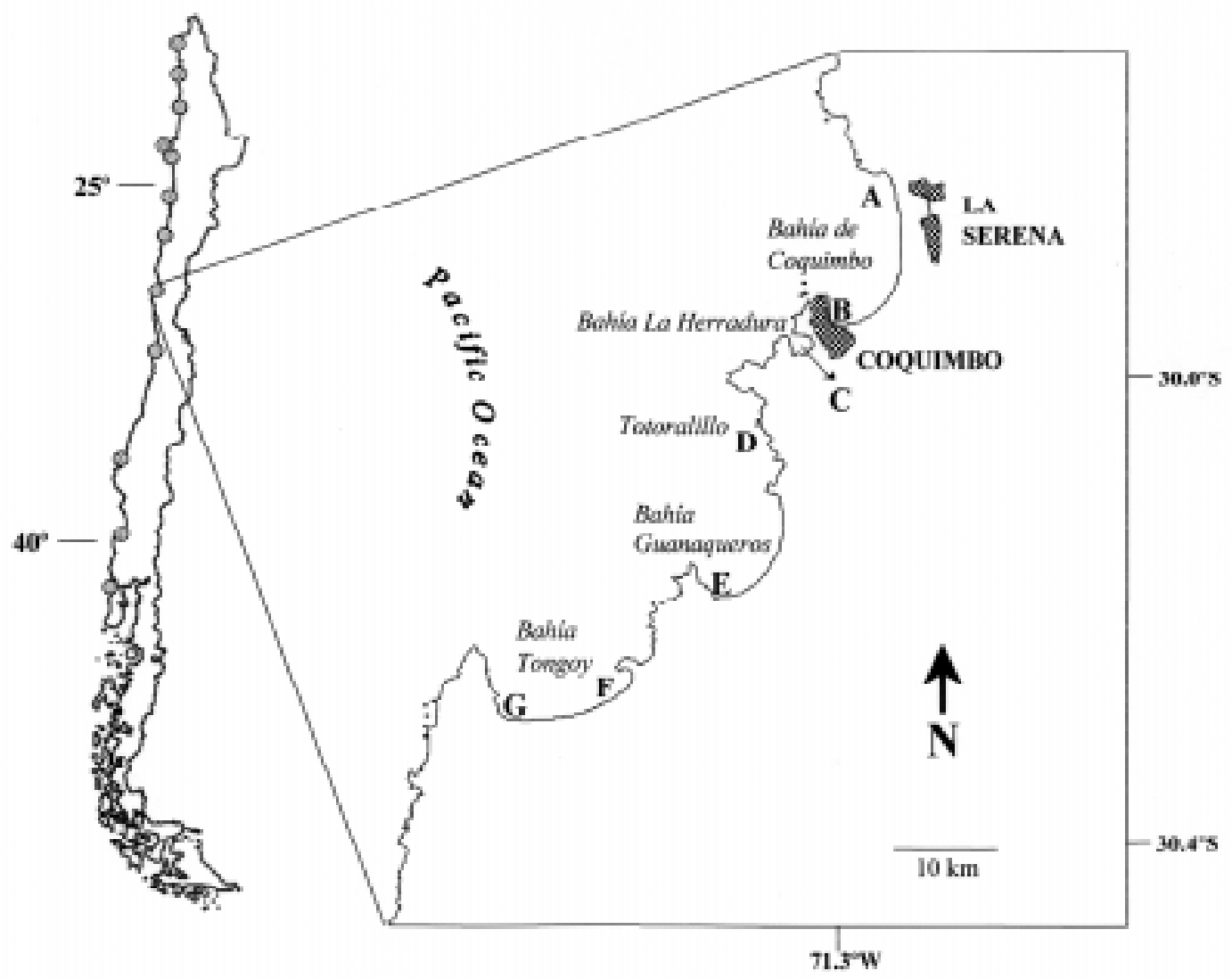

Fig. 1: Bay system investigated in the present study. Samples were taken from buoys, seagrass and algal beds, and boulders on exposed rocky shores along stations A-G; the three different substrata were not present at all sampling stations. Dots along the Pacific coast of continental Chile indicate sampling sites for regional study.

Sistema de bahías investigado en el presente estudio. Las muestras fueron recolectadas en boyas, praderas y bolones a lo largo de las estaciones A-G. Los tres substratos considerados no siempre estuvieron presentes en todos los puntos de muestreo. Los círculos a lo largo de la costa Pacífico de Chile continental indican los sitios de muestreo del estudio regional.

were more common in these than in other littoral habitats (Guerra-García \& Thiel 2001). At each of the seven sampling sites we attempted to sample all three habitats keeping the minimum distance between different habitats $<1,500 \mathrm{~m}$; at some sites not all habitats were represented. Sessile fauna together with any adhering amphipods was scraped from boulders located in the low intertidal zone. We focused on areas that were colonized by hydrozoans Obelia dichotoma, which we scraped from the underside of several boulders until completing a volume of $10-20 \mathrm{~mL}$. In the subtidal beds of Gracilaria chilensis and Heterozostera tasmanica we collected the principal plant species together with other occasional algae (Callophyllis variegata, Chondracanthus chamissoi, Sarcodiotheca gaudichaudii, Sphaerococcus coronopifolius and Halopteris sp.). Plants were taken from the bottom by a semiautonomous diver and placed in a sampling jar until completing a volume of approximately 1,000 $\mathrm{mL}$. From buoys and ropes associated with aquaculture or harbor structures, we collected the most common epibiota (metazoans such as Pyura chilensis, Bugula neritina and B. flabellata, Tubularia crocea, cirripeds from the family Balanidae; and macroalgae such as Ulva lactuca, Polysiphonia paniculata and P. mollis, Chondracanthus chamissoi, Lessonia trabeculata, often covered with bryozoans of the genus Membranipora) together with the adhering amphipods. Samples were either taken by a semiautonomous diver who separated the fouling organisms from the buoys and ropes and placed them in a sampling jar at the water surface. Alternatively, buoys and ropes were pulled into a boat 
where fouling organisms were separated and immediately placed in the jar. Fouling organisms were gathered from different buoys and ropes until completing a volume of $500 \mathrm{~mL}$.

The main objective of this survey was to determine the species richness of littoral caprellids in different habitats. In order to obtain representative estimates of species, we selected different sample volumes in each habitat $(20 \mathrm{~mL}$ under boulders, $500 \mathrm{~mL}$ in buoys and ropes and 1,000 $\mathrm{mL}$ in algal beds) thereby taking structural differences among habitats into account. Preliminary sampling had indicated that under boulders caprellids cling to small hydroids or to the substratum directly, while on algae they roam over large areas of algal surface. A survey by GuerraGarcía \& Thiel (2001) in the bay system of Coquimbo indicated that the selected sampling volumes are sufficient to obtain representative estimates of species richness in the habitats studied herein. Since this preliminary survey had revealed large differences in caprellid abundance, herein we used a semi-quantitative method in order to estimate caprellid abundances in the different habitats: present (1-10 individuals sample ${ }^{-1}$ ), common (11-100 individuals sample ${ }^{-1}$ ), abundant (101-1,000 individuals sample $\left.{ }^{-1}\right)$ and superabundant ( $>1,000$ individuals sample $\mathrm{e}^{-1}$ ). We expressed the abundance of caprellids as individuals per sample and not as individuals per sample volume thereby taking into account the different habitat structure. The usefulness of a semi-quantitative scale in multivariate analysis has been demonstrated in ecological studies dealing with marine invertebrates (Maldonado \& Uriz 1995, Carballo et al. 1996, Naranjo et al. 1996, Guerra-García 2001). Nevertheless, according to Clarke \& Warwick (1994), when sampling artifacts render quantitative comparisons unfeasible, a reduction to simple presence or absence of each species is recommended. Following these suggestions, similarities of caprellid occurrence among different habitats on the local scale were examined by means of a classification analysis based on presence/absence data instead of the semi-quantitative data. The Jaccard similarity index (Jaccard 1908) and the UPGMA (unweighed pair-group average method) aggregation algorithm (Sneath $\&$ Sokal 1973) were used. The significance of the resulting clusters was established following the bootstrap methodology as in Lancellotti \& Trucco (1993) (after Jaksic \& Medel 1987). From the initial species*habitat matrix with presence/absence data, 1,000 stochastic reassignments were made, computing on each occasion similarity pseudo-values for each possible combination of habitats. All pseudo-values generated after 1,000 shuffles were plotted in a frequency histogram, establishing the significance, i.e., at a 0.05 or $0.10 \alpha$-level, at the $95^{\text {th }}$ or $90^{\text {th }}$ percentile, respectively. The similarity value to which the $95^{\text {th }}$ percentile corresponded was considered the critical value. Thus, for any cluster, a similarity value above this critical value was considered higher than expected at random, and it was considered significant at the $\alpha=0.05$ level.

For the study of the regional distribution of caprellids we focused on the species associated with the fouling community from buoys and ropes, since previous studies had revealed that this is a very important habitat for littoral caprellid species (Bynum 1978, Caine 1987). At 12 different sites between $18.4^{\circ}$ and $41.9^{\circ} \mathrm{S}$, spanning $~ 3,000$ $\mathrm{km}$ along the Pacific coast of continental Chile (Fig. 1), samples were taken from buoys and ropes associated with aquaculture or harbor structures. For Coquimbo we considered the results from Bahía La Herradura (site C in Fig. 1). Sampling was done during austral summer 2001 in the same way as described above. Fouling organisms were separated from different buoys and ropes and placed into the sampling jar until completing a volume of $500 \mathrm{~mL}$. In this way we obtained one cumulative sample for each of the 12 different sites. All samples were fixed with $5 \%$ formalin and later washed over a mesh of $250 \mu \mathrm{m}$ before sorting them in the laboratory. The Bray-Curtis distance index (Bray \& Curtis 1957) and the UPGMA (unweighed pair-group average method) aggregation algorithm (Sneath \& Sokal 1973) were used. The analysis was conducted using the semi-quantitative data, i.e., with an order of magnitude corresponding to a logarithmic transformation, which is typically used for this sort of analysis in order to standardize interspecific variability (Clarke \& Warwick 1994). Before conducting the analysis we added the value of $1 \times 10^{-5}$ to each element in the original matrix, which allowed to incorporate the localities with no caprellids (zero values) into the analysis - this procedure produced no changes in the general association pattern. The significance of the clusters resulting from this analysis was established following the same procedure as on the local scale but based on the species* site semi-quantitative data matrix.

During a two-day oceanographic cruise conducted during the austral fall 2002 in coastal waters off the Bay system of Coquimbo we collected six detached buoys together with their fouling community. Additionally, during several oceanographic cruises along the Chilean coast, which were conducted during austral summer 2002 (nine cruises between Arica, $18^{\circ} \mathrm{S}$, and Isla Madre 
de Dios, $50^{\circ} \mathrm{S}$, each cruise $10-30 \mathrm{Nm}$ off the coast), we collected two detached buoys off the coast at approximately $27^{\circ} \mathrm{S}$. On most occasions we sampled the entire buoy and after washing it over a mesh of $250 \mu \mathrm{m}$ we scraped the fouling community from the buoys. Due to logistic reasons different volumes were sampled of the fouling community from these detached buoys. In all cases the semi-quantitative estimates represent minimum estimates of the total caprellid abundance on each buoy. Following preservation in the field, these samples were processed in the laboratory in the same way as described above. Detailed information about the detached buoys can be found in Appendix 1 .

\section{RESULTS}

\section{Local distribution of caprellids from different} littoral habitats

A total of six caprellid species were collected in different littoral habitats along the bay system of Coquimbo. None of these species was found in all sampled habitats, but some species (Caprella equilibra Say, 1818, C. scaura Templeton, 1836, Deutella venenosa Mayer, 1890) occurred in two of the three studied habitats, while others (Caprellina longicollis (Nicolet, 1849), Caprella verrucosa Boeck, 1871, Paracaprella pusilla Mayer, 1890) were only found in one of these habitats (Table 1). The species C. scaura was one of the most widespread species, being common in almost all samples from buoys and present in all samples from algal and seagrass beds. Although the presence of $C$. scaura in algal and seagrass beds was constant along the bay system studied, its abundance was comparatively low, never exceeding 10 individuals per sample. The species D. venenosa was very abundant on buoys and did also occur under intertidal boulders. Caprella verrucosa also was very abundant on buoys but did not occur in any of the other two habitats. Caprella equilibra was present on some buoys, but also occurred under boulders together with $D$. venenosa, both species being associated with the hydroid Obelia dichotoma. The presence of Paracaprella pusilla was restricted to the boulders from sampling site C. Caprellina longicollis

\title{
TABLE 1
}

Abundance of caprellid species in the different habitats (1 - buoys, 2 - algal and seagrass beds, 3 - boulders) and the sampling sites (A-G) in the bay system of Coquimbo; (*) indicates the seagrass bed; sample volume for buoys is $500 \mathrm{~mL}$, for algal and seagrass beds is $1,000 \mathrm{~mL}$ and for boulders approximately $20 \mathrm{~mL}$. For further details see text

\begin{abstract}
Abundancia de las especies de caprélidos en los distintos hábitats ( 1 - boyas, 2 - praderas, 3 - bolones) y estaciones muestreadas (A-G) a lo largo del sistema de bahías de Coquimbo; (*) indica la pradera de fanerógama. El volumen de muestreo para boyas fue $500 \mathrm{~mL}$, para praderas $1.000 \mathrm{~mL}$ y para bolones aproximadamente $20 \mathrm{~mL}$. Ver texto para más detalles
\end{abstract}

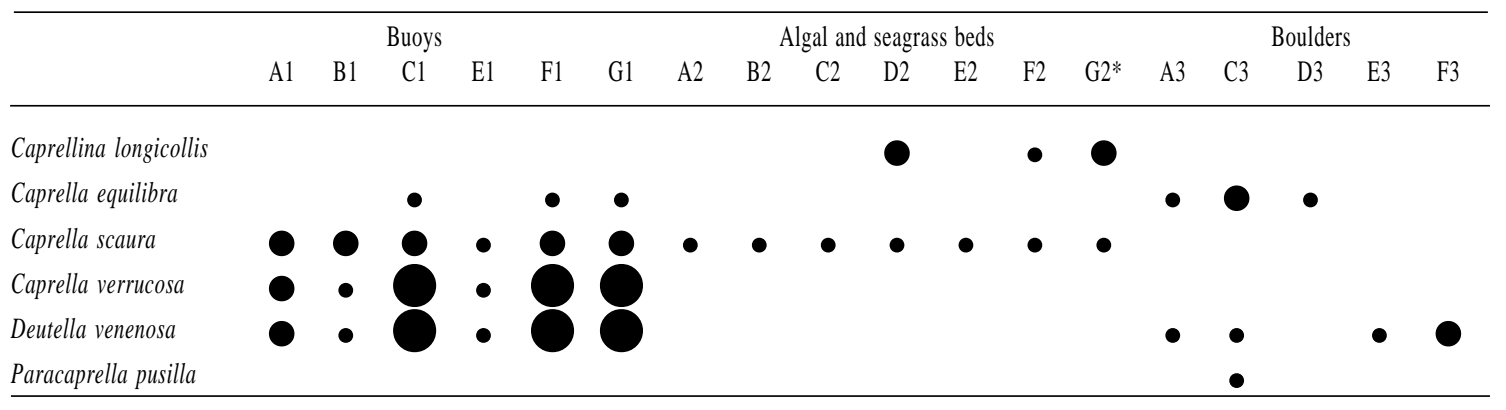
(A) Bahía de Coquimbo, north
(B) Bahía de Coquimbo, south
(C) Bahía de La Herradura
(D) Bahía de Totoralillo
(E) Bahía de Guanaqueros
(F) Bahía de Tongoy, north
(G) Bahía de Tongoy, south
(*) Seagrass bed (Heterozostera tasmanica)

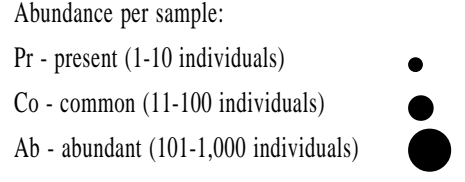

Abundance per sample:

Pr - present (1-10 individuals)

$\mathrm{Ab}$ - abundant (101-1,000 individuals) 
was, together with $C$. scaura, the only species recorded from the algal and seagrass beds.

The epifouling community from buoys and ropes was the habitat with the highest species richness and abundance of littoral caprellids. The caprellid fauna differed among the studied habitats, but on a local scale (tens of $\mathrm{km}$ ) little variation was found within habitats, with the exception of boulders (Fig. 2). The samples from buoys and algal/ seagrass beds were grouped in two separate groups, both connecting two subgroups. While the group connecting caprellid fauna from buoys was significant $(\mathrm{P}<0.05)$, those from the algal/ seagrass beds formed distinct subgroups at $0.10>$ $\mathrm{P}>0.05$. In contrast, samples from boulders formed no distinct group suggesting a comparatively heterogeneous habitat, possibly exposed to frequent extinction/colonization events.

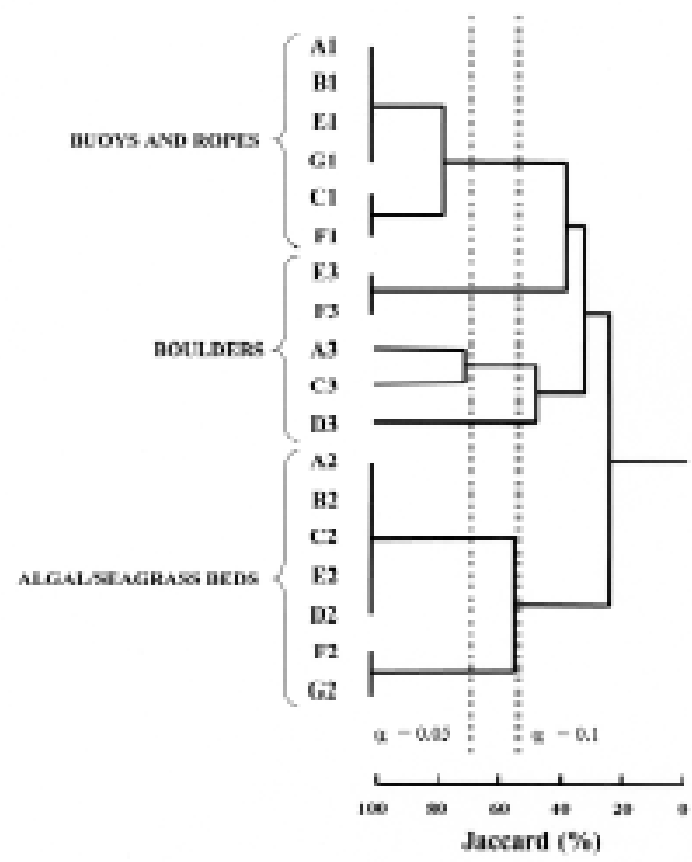

Fig. 2: Cluster analysis showing the relationships among samples on the local scale. Similarities based on presence/absence of caprellid species on different substrata (buoys: 1, algal/seagrass beds: 2; boulders: 3 ) and sampling stations (A-G). Dashed lines indicate significant levels: Groups of habitats 1 (buoys) and 2 (algal/seagrass beds) significant at $0.10>\mathrm{P}>0.05$.

Análisis de conglomerados mostrando las relaciones entre substratos en una escala local. Las similitudes están basadas sobre la presencia/ausencia de caprélidos en los diferentes substratos (boyas: 1, praderas: 2; bolones: 3 ) y estaciones de muestreo (A-G). Las líneas sombreadas indican niveles de significancia: los grupos de hábitats 1 (boyas) y 2 (praderas) fueron significativos a una probabilidad $0,10>\mathrm{P}>0,05$.
Regional distribution of caprellids associated with anchored buoys

Four caprellid species were found on the anchored buoys along the Chilean coast (Fig. 3). Similar as in the bay system of Coquimbo, Caprella verrucosa and C. scaura were the most abundant species on buoys, being widely distributed in the northern region of the Chilean coast. Caprella equilibra was only present in a few localities and the species Deutella venenosa only occurred in Coquimbo. Both, abundance and species richness of caprellids on the buoys and ropes decreased from north to south, and no caprellids were found in the southern region (at $39.8^{\circ}$ and $41.9^{\circ} \mathrm{S}$ ) (Fig. 3). The classification analysis showed three distinct clusters, one in the northern region characterized by relatively high species richness and abundances, where two subgroups are connected with $\mathrm{P}<0.10$, one in the central region with higher heterogeneity, where species richness and abundance decreased, and one in the south where no littoral caprellids were found in the fouling community associated with buoys (Fig. $4)$.

Some intraspecific morphological variation has been found for Caprella scaura and C. verrucosa at some sites. The striking head spine, typical of $C$. scaura reported throughout the world, was very reduced in the specimens collected from Isla Sta. Maria $\left(23.4^{\circ} \mathrm{S}\right)$. Nevertheless, examination of antennae, gnathopods, mouthparts and abdomen of these specimens confirmed that they belonged to C. scaura. In the specimens of Caprella verrucosa from Caleta Tumbes $\left(36.6^{\circ} \mathrm{S}\right)$, the southernmost station where caprellids were found, the tubercles on the dorsal pereonites were absent. Taking in consideration the features of antennae, these specimens were assigned to $C$. verrucosa. These observations, however, confirm the great need for future taxonomic studies in the complex of species similar to C. verrucosa (see also Guerra-García \& Thiel 2001). Regardless of the morphological variations in some of the specimens found herein, a strong decrease in abundance and species richness of littoral caprellid towards higher latitudes was found (Fig. 3).

Caprellids associated with detached (= pelagic) buoys

On the six detached buoys that were collected while floating in coastal waters off the Bay system of Coquimbo, a total of four different caprellid species was found (Table 2). The most common caprellid species were Caprella scaura and $C$. 


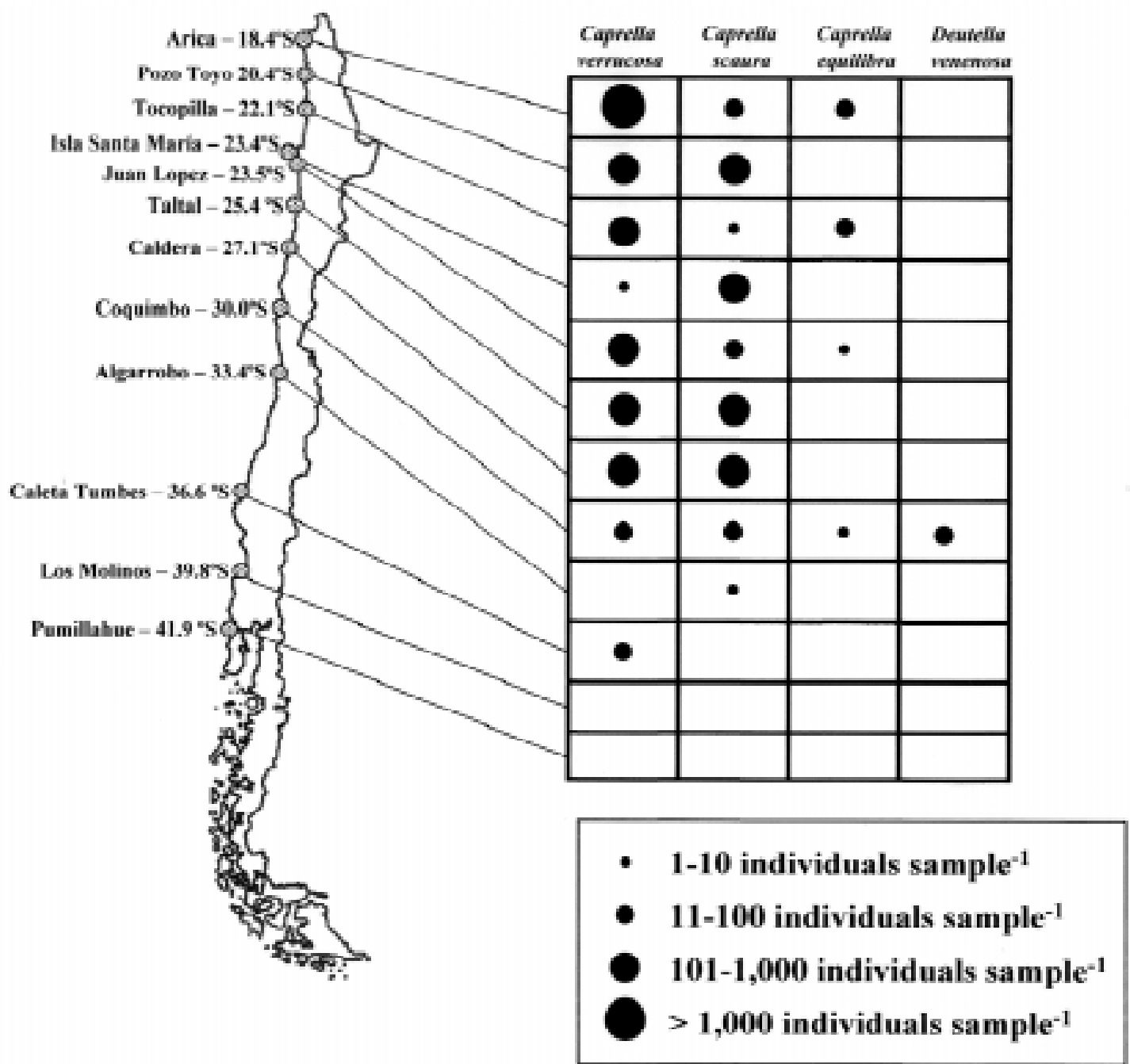

Fig. 3: Abundance and distribution of the caprellid species associated with the fouling community of buoys and ropes along the Pacific coast of continental Chile. At each site, epifaunal organisms from different buoys and ropes were gathered until completing a volume of $500 \mathrm{~mL}$.

Abundancia y distribución de los caprélidos asociados a la comunidad epifita de boyas y cuerdas a lo largo de la costa Pacífico de Chile continental. En cada localidad, se recolectaron organismos epífitos de diferentes boyas y cuerdas hasta completar un volumen de $500 \mathrm{~mL}$.

equilibra, which were each found on four of the six buoys. The other two caprellid species, $C$. verrucosa and Deutella venenosa, were each found on two buoys. Abundances of individual caprellid species frequently exceeded 100 s of individuals per buoy (Table 2). On all buoys, we also found ovigerous females.

During the nine research cruises between Arica and Isla Madre de Dios we found two detached buoys floating in coastal waters off Caldera. Each of these two buoys harbored three caprellid species (C. equilibra, C. scaura and $C$. verrucosa) (Table 2). Abundances of C. equilibra was highest on the buoys itself, while $C$. scaura dominated on the rope still attached to one of these two buoys. Of all three caprellid species and on each of the two buoys, ovigerous females were found.

\section{DISCUSSION}

The results of the present study demonstrated that the caprellid fauna along the Pacific coast of continental Chile is comparatively poor. Despite a relatively large sampling effort on the local and regional scale only six species of littoral caprellids were found. Regardless of the low species number, distinct geographic patterns were found. In 


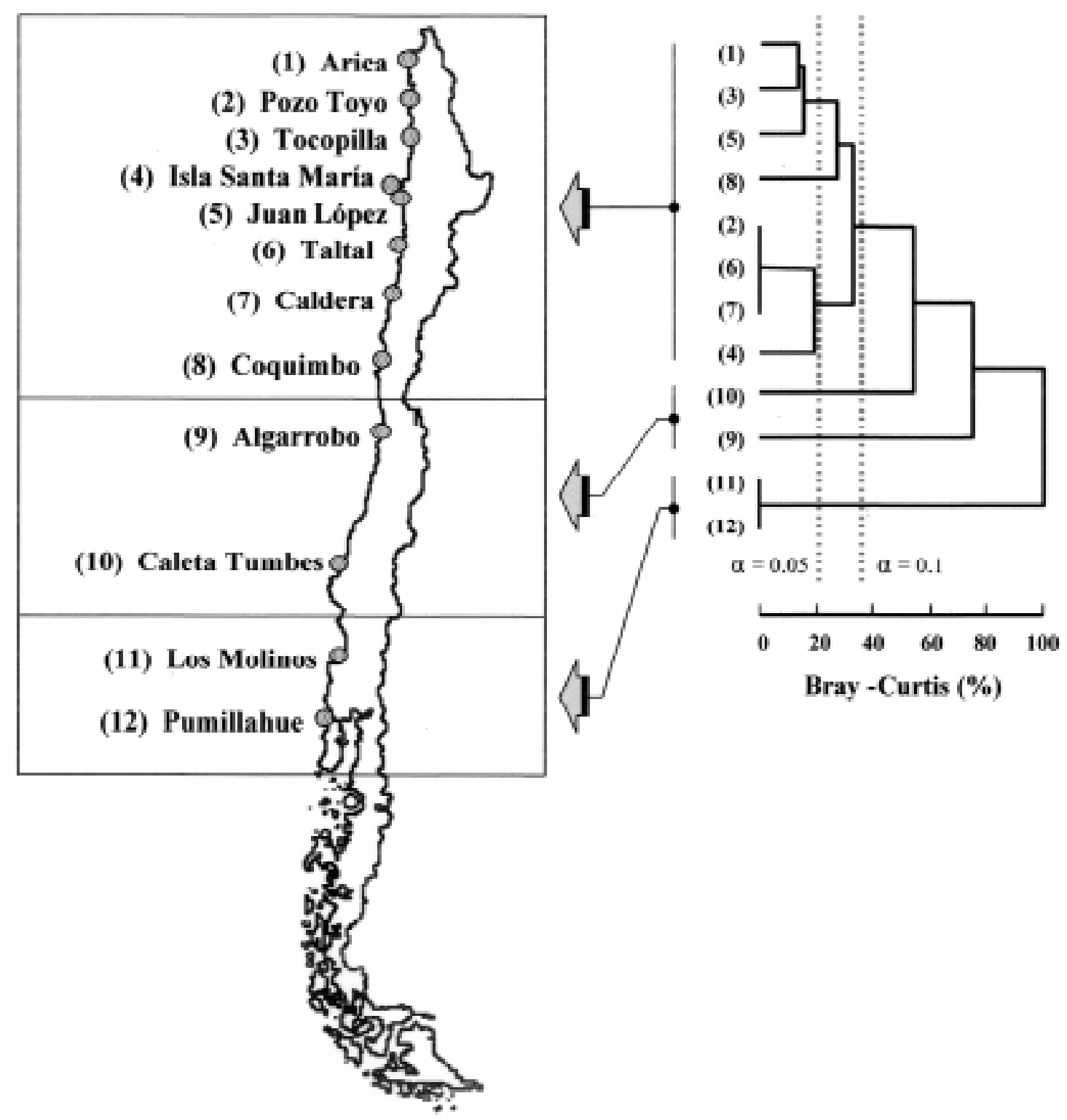

Fig. 4: Cluster analysis showing the relationships among sampling sites along the Pacific coast of continental Chile (regional scale). Distance was based on semi-quantitative values of caprellid abundance. Dashed lines indicate significant levels: group of sampling sites from the northern region significant at $0.10>\mathrm{P}>0.05$.

Análisis de conglomerados mostrando las relaciones entre las localidades de muestreo a lo largo de la costa del Pacífico de Chile continental (escala regional). Las distancias están basadas en los valores semi-cuantitativos de la abundancia de caprélidos. Las líneas sombreadas indican niveles de significancia: el grupo de estaciones de muestreo de la región norte fue significativo a una probabilidad $0,10>\mathrm{P}>0,05$.

the following we will compare the distribution patterns of littoral caprellids on different geographic scales, and we discuss the factors influencing these patterns.
Local distribution of caprellid species in the bay system of Coquimbo

Within the bay system examined herein, most caprellid species were found in two types of habitat. Those habitats were very different (e.g., foul- 
TABLE 2

Abundance of caprellid species on detached buoys off the Pacific coast of Chile: present (1-10 individuals); common (11-100 individuals); abundant (101-1,000 individuals); superabundant (>1,000 individuals). All abundance estimates represent minimum values; (Cq) Coquimbo; (Ca) Caldera. For details about buoys see Appendix 1

Abundancia de las especies de caprélidos en boyas desprendidas y encontradas frente a la costa Pacífico de Chile: presente (1-10 individuos); común (11-100 individuos); abundante (101-1.000 individuos); superabundante (>1.000 individuos). Todas las estimaciones de abundancia representan valores mínimos; (Cq) Coquimbo; (Ca) Caldera. Para más detalles ver Anexo 1

\begin{tabular}{|c|c|c|c|c|c|c|c|c|c|c|}
\hline & \multicolumn{7}{|c|}{ Coquimbo } & \multicolumn{3}{|c|}{ Caldera } \\
\hline & $\mathrm{Cq} 1$ & $\mathrm{Cq} 2-\mathrm{b}$ & $\mathrm{Cq} 2-\mathrm{r}$ & $\mathrm{Cq} 3$ & $\mathrm{Cq} 4$ & $\mathrm{Cq} 5$ & $\mathrm{Cq} 6$ & Cal & $\mathrm{Ca} 2-\mathrm{b}$ & Ca2-r \\
\hline Sample type & Buoy & Buoy & Rope & Buoy & Buoy & Buoy & Buoy & Buoy & Buoy & Rope \\
\hline Latitude & 29049'23"' & 29047’06" & & $29058^{\prime} 38^{\prime \prime}$ & $30^{\circ} 03^{\prime} 56^{\prime \prime}$ & $30^{\circ} 13^{\prime} 00^{\prime \prime}$ & $29037^{\prime} 59^{\prime \prime}$ & $27^{\circ} 01^{\prime} 23 "$ & $27^{\circ} 05^{\prime} 45^{\prime \prime}$ & \\
\hline Longitude & $71^{\circ} 26^{\prime} 39^{\prime \prime}$ & $71^{\circ} 27^{\prime} 44^{\prime \prime}$ & & $71^{\circ} 24^{\prime} 59^{\prime \prime}$ & $71^{\circ} 40^{\prime} 55^{\prime \prime}$ & $71^{\circ} 42^{\prime} 35^{\prime \prime}$ & 71031'33" & $70^{0} 56^{\prime} 55^{\prime \prime}$ & $71^{\circ} 00^{\prime} 15^{\prime \prime}$ & \\
\hline Distance from shore $(\mathrm{km})$ & 12.5 & 11.8 & & 1.9 & 19.7 & 7.7 & 20 & 6.8 & 6.5 & \\
\hline \multicolumn{11}{|l|}{ Caprellina longicollis } \\
\hline \multicolumn{11}{|l|}{ Caprella equilibra } \\
\hline \multicolumn{11}{|l|}{ Caprella scaura } \\
\hline \multicolumn{11}{|l|}{ Caprella verrucosa } \\
\hline \multicolumn{11}{|l|}{ Deutella venenosa } \\
\hline Paracaprella pusilla & & & & & & & & & & \\
\hline
\end{tabular}

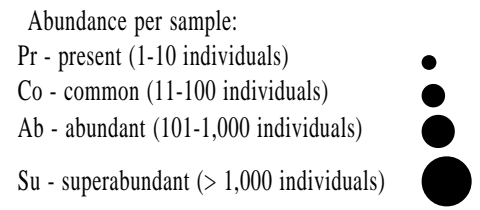

ing community on buoys and ropes versus algal and seagrass beds) suggesting that the caprellid species found in the bay system of Coquimbo are relatively unselective with respect to their substratum, which appears to be generally true for littoral caprellid species. For example, Caprella scaura has been reported from bryozoans, sponges, seaweeds and seagrasses (Lim \& Alexander 1986, Takeuchi \& Hino 1997, Serejo 1998). Caprella equilibra has been collected from seaweeds, bryozoans, sponges and ascidians (Krapp-Schickel 1993). Aoki \& Kikuchi (1990) found C. verrucosa on very different substrata, and Caprellina longicollis has been collected from algae, bryozoans and ascidians along the coast of New Zealand, where it is the most abundant species (McCain 1969). Mayer (1890) reported that C. verrucosa and $D$. venenosa were often found on various substrata belonging to the fouling community along the coast of Coquimbo. In general, at the local scale, the environmental habitat conditions (such as hydrodynamics, sedimentation rate, turbidity, substratum stability) seem to be more important in determining the distribution of littoral caprellids than substratum characteristics (Takeuchi et al. 1987, 1990, Guerra-García \& García-Gómez 2001). Recently, Guerra-García \& García-Gómez (2001) found that the species composition of the Caprellidea from one particular substratum (the seaweed Cystoseira usneoides) along the coast of Ceuta (North Africa) changed considerably according to environmental factors such as local hydrodynamics. This suggests that environmental conditions are usually more important in determining the distribution of littoral caprellids than substratum characteristics. The importance of hydrodynamic conditions for the distribution of littoral caprellids is not surprising since many species feed directly on organisms or materials captured from the water column (Takeuchi \& Hirano 1995).

Hydrodynamic conditions may also have implications for caprellid dispersal within bay systems. Most bays along the continental coast of Chile are characterized by strong circulation and efficient mixing of surface waters (Sobarzo 2002). This contributes to efficient exchange and a relatively uniform distribution pattern of benthic spe- 
cies within such bays or bay systems (Castilla et al. 2002). Apparently buoys, anchored in the bays along the Chilean coast, are frequently detached together with their caprellid fauna and subsequently moved by predominant currents within bay systems. This process may contribute to frequent dispersal and thereby to the relatively uniform distribution pattern of littoral caprellid species within the bay system of Coquimbo.

\section{Regional distribution of caprellids along the Pa- cific coast of continental Chile}

The regional sampling revealed a latitudinal gradient with littoral caprellids being abundant in the northern region of Chile, but virtually absent from buoys and ropes at the southern sites $\left(39.8^{\circ}\right.$ and $41.9^{\circ} \mathrm{S}$ ) examined herein. The latitudinal change in the distribution of littoral caprellids takes place in the central region of the continental coast of Chile, where important faunal changes have been identified for a variety of taxa and functional groups (e.g., Lancellotti \& Vásquez 2000, Ojeda et al. 2000, Camus 2001, Rivadeneira et al. 2002, Thiel 2002). Most of these authors agree that northern species disappear between $30^{\circ}$ and $37^{\circ} \mathrm{S}$, being gradually displaced by southern species, some of which may reach as far north as $25^{\circ} \mathrm{S}$. This overlap of southern and northern species in the central region of Chile in some groups results in highest regional species richness in this region (e.g., Rivadeneira et al. 2002). This trend may be reenforced by the presence of other species that only occur in the central region (Thiel 2002). Along the continental coast of Chile, in some taxa the overall species richness decreases towards higher latitudes (e.g., in littoral fishes - Ojeda et al. 2000), while it increases in others (e.g., bryozoans Moyano 1991). Herein we observed the total disappearance of littoral caprellids from anchored buoys south of $37^{\circ} \mathrm{S}$, without replacement by southern species. Similar observations have also been made for some taxa in other regions of the world (corals - Fraser \& Currie 1996; prosobranch gastropods, bivalves - Roy et al. 1998, 2000). In these studies the observed decrease in species richness or diversity towards higher latitudes was best correlated with decreasing sea surface temperature, but the ultimate factors (productivity, predation, competition, disturbance) are not well known.

\section{Global distribution of littoral caprellid species}

In general, the number of caprellid species found along the coast of Chile on the local and regional scale is very low when compared with other areas at similar latitudes. In Japan, Takeuchi et al. (1987) found 16 caprellid species in a bed of Sargassum spp. that had a maximal extension of only $100 \mathrm{~m}$ x $80 \mathrm{~m}$. Aoki \& Kikuchi (1990), also in Japan, found nine caprellid species in just one bed of Sargassum patens $400 \mathrm{~m}$ long and $100 \mathrm{~m}$ wide. Takeuchi \& Hino (1997) cite 10 caprellid species associated with seagrass beds in the Bay of Otsuchi in Japan, and in Brazil, Serejo (1998) found five caprellid species associated with only one species of sponge, Dysidea fragilis. In Bahía de Algeciras, southern Spain, Sánchez-Moyano \& García-Gómez (1998) cite nine caprellid species associated with a single algal species, Halopteris scoparia. Guerra-García \& Takeuchi (2002) found 19 caprellid species in the littoral zone of Ceuta (a $10 \mathrm{~km}$ long stretch of coastline) in northern Africa. Most of these reports are from areas with temperate water conditions. In contrast to the relatively high values of species richness reported from other areas, in a seagrass bed of Heterozostera tasmanica in Bahía de Tongoy, Chile, González (1990) found only two caprellid species, and in a study by Alcayaga (1990) on the fauna associated with a bivalve culture in the same bay, only one caprellid species was reported. Presently, the reasons for the low species richness of littoral caprellids along the Pacific coast of continental Chile are not well known. Caprellid amphipods have also been reported from further south than $37^{\circ} \mathrm{S}$, for example from the Magellan Strait (Schellenberg 1935), but little is known about their abundance in this region with predominantly cold waters. Thus, caprellid amphipods can be found all along the Pacific coast of Chile, but abundance and species richness of littoral species associated with the fouling community on buoys is highest in the northern region.

Although the biogeographical distribution of caprellid species on a global scale is not well known so far, Laubitz (1970) studied the caprellids from intertidal and shallow waters along the North Pacific from the zoogeographical point of view. She found that the major limiting factor in the distribution of the caprellid species was water temperature; most of the species occurred almost exclusively in the $10-15{ }^{\circ} \mathrm{C}$ temperature range (from Alexander Archipelago to the Strait of Georgia) and only a few species were found in the subantarctic range $5-10^{\circ} \mathrm{C}$. This pattern is similar to that revealed for the Southeast Pacific in the present study. The abundance and species richness of littoral caprellids decreases towards high latitudes with cold surface waters. Along the Chilean coast we found the highest abundances at $18^{\circ} \mathrm{S}$, i.e., closer to the Equator than in the North 
Pacific. In the eastern North Pacific, caprellid abundance starts declining only at $\sim 50^{\circ} \mathrm{N}$, while in our study of littoral caprellids from the eastern South Pacific already at $37^{\circ} \mathrm{S}$ no caprellids were found. For example, Laubitz (1970) reported that Caprella equilibra and C. verrucosa had not been recorded north of the Queen Charlotte Islands $\left(\sim 49^{\circ} \mathrm{N}\right)$, but on the continental coast of the eastern South Pacific these species did not occur further south than $37^{\circ} \mathrm{S}$. The differences between the eastern North Pacific and the South Pacific could be due to the strong effect of the cold Humboldt Current moving northwards along the Chilean coast.

Similar as in the eastern Pacific, the distribution of littoral caprellids in the south-western
Pacific appears to underscore the importance of oceanographic currents and water temperature. Tasmania is situated approximately at the same latitude as Southern Chile, but the number of littoral species is relatively high (approximately 20 species - Guiler 1954, J. Guerra-García \& I. Takeuchi unpublished results), comparable with other areas of Australia (J. Guerra-García, unpublished results). This high species richness in Tasmania and the deviation from the general pattern (see Fig. 5) probably is affected by the warm East Australian Current, moving southwards along the coast of Eastern Australia extending its influence up to Tasmania. For New Zealand, which at least at its southern island is very similar to the coast of Southern Chile with respect to the oceano-
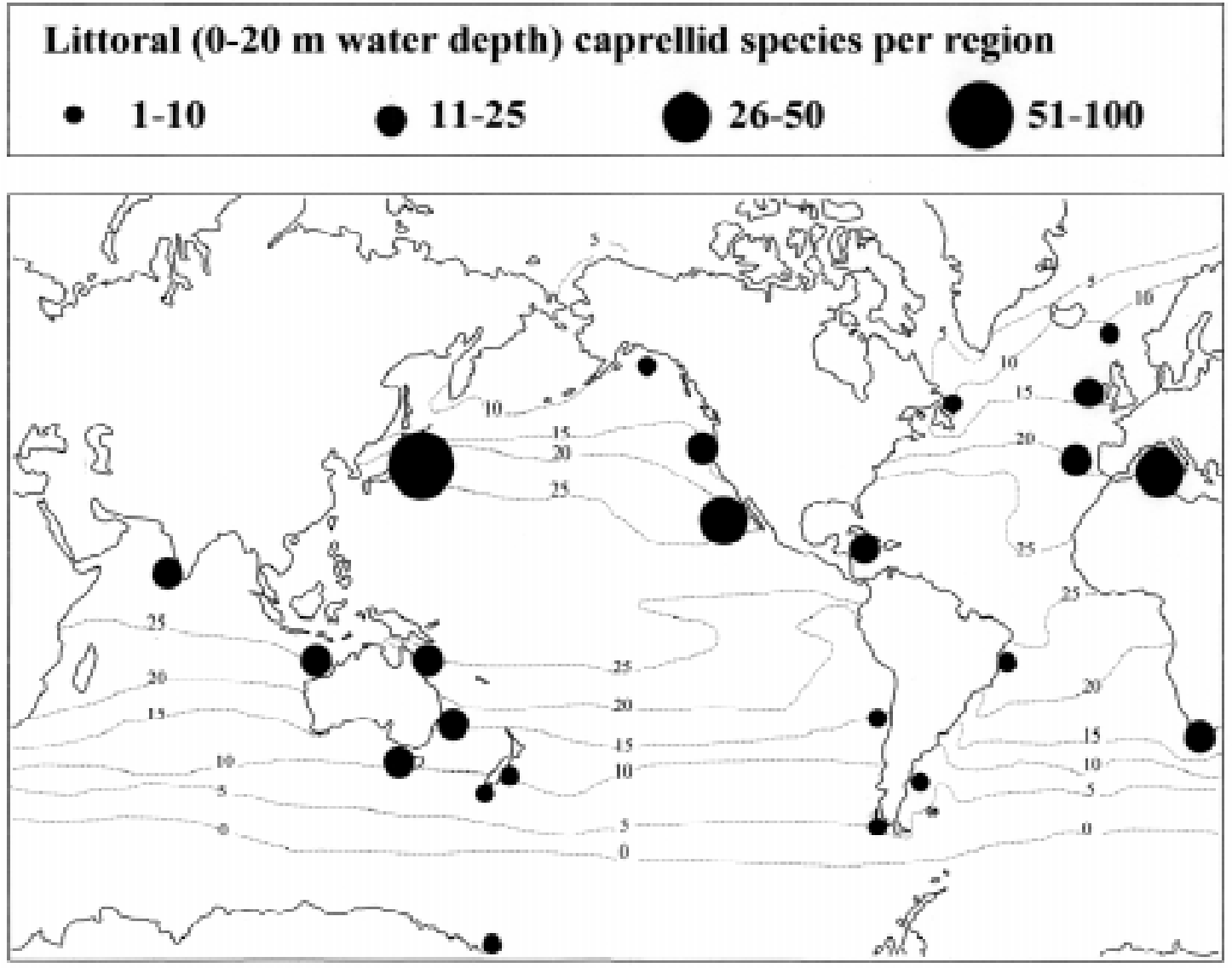

Fig. 5: World map with isolines of sea surface temperature $\left({ }^{\circ} \mathrm{C}\right)$ and approximate number of littoral caprellid species reported from different regions. Data are taken from Schellenberg (1935), McCain (1968, 1969), McCain \& Steinberg (1970), Laubitz (1970, 1972), McCain \& Gray (1971), Griffiths (1976), Sivaprakasam (1977), Marques \& Bellan-Santini (1985), Swaldon (1990), Wakabara et al. (1991), Watling (1996), Larsen (1998), Serejo (1998), Takeuchi (1999), Guerra-García \& Takeuchi (2002, unpublished results).

Mapamundi de las isolíneas de temperatura superficial del agua $\left({ }^{\circ} \mathrm{C}\right)$ y número aproximado de especies de caprélidos litorales citados en diferentes regiones. Los datos están tomados de Schellenberg (1935), McCain (1968, 1969), McCain \& Steinberg (1970), Laubitz (1970, 1972), McCain \& Gray (1971), Griffiths (1976), Sivaprakasam (1977), Marques \& Bellan-Santini (1985), Swaldon (1990), Wakabara et al. (1991), Watling (1996), Larsen (1998), Serejo (1998), Takeuchi (1999), Guerra-García \& Takeuchi (2002, resultados no-publicados). 
graphic conditions, only three species of littoral caprellids have been reported (McCain 1969).

The decrease of caprellid abundance and diversity towards colder waters as observed in the eastern Pacific Ocean can also be observed in other regions of the world (Fig. 5). Even though Laubitz (1972) and Larsen (1998) reported the presence of more than 25 species in cold waters around the Arctic Atlantic, most of them inhabit the deep sea and only a few species are littoral. Similarly for Antarctica, where the period of isolation of the fauna has favored the process of speciation (Clarke \& Crame 1993), the number of littoral species is also low, even though 20 species have been reported from the Antarctic deep sea (McCain \& Gray 1971). In summary, the latitudinal pattern observed along the Pacific coasts appears to reflect global trends with decreasing species richness towards higher latitudes.

\section{Dispersal of caprellid crustaceans and biogeo- graphical implications}

Passive dispersal via rafting and floating are supposed to be the main migration mechanisms for small crustaceans with direct development (Highsmith 1985, Locke \& Corey 1989). The occurrence of most caprellids encountered in this study on substrata with high dispersal potential (macroalgae, fouling community associated with buoys and other floating materials) may also explain their relatively uniform distribution on the local scale. At most sites from the northern region of the study area, the three most common caprellid species occurred frequently on anchored buoys. Upon being detached, these substrata may be easily distributed over distances on the local (tens of $\mathrm{km}$ ) and regional (hundreds of $\mathrm{km}$ ) scale. Jara \& Jaramillo (1979), reporting on a detached buoy captured a few $\mathrm{km}$ off the coast near Maiquillahue, Chile $\left(39.4^{\circ} \mathrm{S}\right)$, discuss the possibility that such objects may be transported over large distances within the West Wind Drift. Floating objects may during their journey carry with them many associated species, such as for example caprellids (Ingólfsson 1995, Hobday 2000a, 2000b). This idea is supported by the finding of all four caprellid species, which usually inhabit the fouling community on anchored buoys, rafting on detached buoys several $\mathrm{km}$ offshore. Rafting has also been suggested by Aoki \& Asakura (1995), who discussed that the caprellid fauna on the Ogasawara Islands may have colonized this oceanic island from source populations of the Japanese Islands or the Asian mainland. Some caprellid species seem to be specially prone to passive rafting as appears to be the case of Caprella andreae, which adapted to ecologically isolated habitats such as drifting objects, possibly evolving from a benthic species, related to C. acutifrons (Aoki \& Kikuchi 1995). In a study of the planktonic distribution of caprellid amphipods in the western North Pacific, Takeuchi \& Sawamoto (1998) found that $C$. equilibra was the dominant species in the plankton samples, suggesting that this species has a greater tolerance for longer periods of planktonic dispersal than other caprellids; it is not known, though, whether the specimens collected in these plankton samples were associated with floating substrata, such as macroalgae. Caprella equilibra, as well as $C$. scaura, is often associated with artificial constructions such as aquaculture nets and floating docks (Takeuchi \& Sawamoto 1998, this study), both substrata with a high rafting potential. Rafting substrata also occur abundantly at high latitudes (Barnes 2002, Smith 2002), and thus the geographic distribution pattern of littoral caprellid species does not appear to be limited by lack of dispersal substrata, although oceanographic currents might impose restrictions on dispersal frequency and direction of littoral caprellids. However, the occurrence of some individuals (but not the large numbers found in the northern region) of C. scaura and of C. verrucosa at $33.4^{\circ}$ and at $36.6^{\circ} \mathrm{S}$ suggests that dispersal (if important) might not be the only factor limiting the geographic distribution of littoral caprellids along the coast of Chile. Rather other factors (productivity, predation, competition, disturbance) that are mediated by sea surface temperature may be responsible for the observed disappearance of littoral caprellids towards higher latitudes, such as has been proposed for other taxa (Fraser \& Currie 1996, Roy et al. 1998, 2000, Rivadeneira et al. 2002).

\section{ACKNOWLEDGEMENTS}

This study was supported by FONDECYT $3980002 \& 1010356$ to MT and through a fellowship of the Ministerio de Educación y Cultura de España (AP98-28617065) to JMGG. We are most grateful to A. Zander for her cheerful assistance during the sampling of caprellids and to numerous fishermen who always were willing to lend us a hand and boat. Helpful comments by A. Baeza, R. Callaway and very constructive suggestions by two anonymous reviewers substantially improved the manuscript. 


\section{LITERATURE CITED}

ALCAYAGA CP (1990) Distribución temporal y batimétrica de organismos incrustantes a valvas inertes de Argopecten purpuratus, Lamarck 1819, en Bahía de Tongoy, Coquimbo. Unpublished Thesis, Universidad Católica del Norte, Coquimbo, Chile. $108 \mathrm{pp}$.

AOKI M \& T KIKUCHI (1990) Habitat adaptations of caprellid amphipods and the importance of epiphytic secondary habitats in a Sargassum patens bed in Amakusa, southern Japan. Publications from the Amakusa Marine Biological Laboratory 10: 123-133.

AOKI M \& A ASAKURA (1995) Caprellids (Crustacea: Amphipoda: Caprellidae) collected from the Ogasawara (Bonin) Islands. Journal of Natural History of the Museum Chiba 3: 191-194.

AOKI M \& T KIKUCHI (1995) Notes on Caprella andreae Mayer, 1890 (Crustacea: Amphipoda) from the carapace of Loggerhead Sea Turtles in the East China Sea and in Kyushu, Japan. Proceedings of the Japan Society of Systematic Zoology 53: 54-61.

BARNES DKA (2002) Invasions by marine life on plastic debris. Nature 416: 808-809.

BRAY RJ \& JI CURTIS (1957) An ordination of the upland forest communities of southern Wisconsin. Ecological Monographs 27: 325-349.

BYNUM KH (1978) Reproductive biology of Caprella penantis Leach, 1814 (Amphipoda: Caprellidae) in North Carolina, USA. Estuarine and Coastal Marine Science 7: 473-485.

CAINE EA (1974) Comparative functional morphology of feeding in three species of caprellids (Crustacea, Amphipoda) from the Northwestern Florida Gulf coast. Journal of Experimental Marine Biology and Ecology 15: 81-96.

CAINE EA (1979) Functions of swimming setae within caprellid amphipods (Crustacea). Biological Bulletin 156: $169-178$.

CAINE EA (1987) Potential effect of floating dock communities on a South Carolina estuary. Journal of Experimental Marine Biology and Ecology 108: 8391.

CAINE EA (1989) Caprellid amphipod behavior and predatory strikes by fish. Journal of Experimental Marine Biology and Ecology 126: 173-180.

CAINE EA (1991) Caprellid amphipods: fast food for the reproductively active. Journal of Experimental Marine Biology and Ecology 148: 27-33.

CAMUS PA (2001) Biogeografía marina de Chile continental. Revista Chilena de Historia Natural 74: 587617.

CARBALLO JL, SA NARANJO \& JC GARCÍA-GÓMEZ (1996) Use of marine sponges as stress indicators in marine ecosystems at Algeciras Bay (southern Iberian Peninsula). Marine Ecology Progress Series 135: 109-122.

CASTILLA JC, NA LAGOS, GUIÑEZ R \& JL LARGIER (2002) Embayments and nearshore retention of plankton: the Antofagasta Bay and other examples. In: Castilla JC \& JL Largier (eds) The oceanography and ecology of the nearshore and bays in Chile: 179-203. Ediciones Universidad Católica de Chile, Santiago, Chile.
CLARKE A \& JA CRAME (1992) The Southern Ocean benthic fauna and climate change: a historical perspective. Philosophical Transactions of the Royal Society B 338: 299-309.

CLARKE KR \& RM WARWICK (1994) Change in marine communities: an approach to statistical analysis and interpretation. Natural Environmental Research Council, United Kingdom. 144 pp.

FRASER RH \& DJ CURRIE (1996) The species richnessenergy hypothesis in a system where historical factors are thought to prevail: coral reefs. American Naturalist 148: 138-159.

GONZÁLEZ SA (1990) Heterozostera tasmanica (Martes ex Aschers.) den Hartog y comunidad asociada en el norte de Chile. Unpublished Thesis, Universidad Católica del Norte, Coquimbo, Chile, pp. 1-119.

GRIFFITHS CL (1976) Guide to the benthic marine amphipods of Southern Africa. Trustees of the South African Museum, Cape Town, South Africa. 106 pp.

GUERRA-GARCÍA JM (2001) Habitat use of the Caprellidea (Crustacea: Amphipoda) from Ceuta, North Africa. Ophelia 55: 27-38.

GUERRA-GARCÍA JM \& JC GARCÍA-GÓMEZ (2001) The spatial distribution of Caprellidea (Crustacea: Amphipoda): a stress bioindicator in Ceuta (North Africa, Gibraltar area. Pubblicazioni della Stazione Zoologica di Napoli: Marine Ecology 22: 357-367.

GUERRA-GARCÍA JM \& M THIEL (2001) The caprellid fauna (Crustacea: Amphipoda: Caprellidea) from Coquimbo, Northern-central Chile with a taxonomic key for species identification. Revista Chilena de Historia Natural 74: 873-883.

GUERRA-GARCÍA JM \& I TAKEUCHI (2002) The Caprellidea from Ceuta, North Africa, with description of three species of Caprella, key for Caprella and biogeographic discussion. Journal of Natural History 36: 675-714.

GUILER ER (1954) Some collections of caprellids from Tasmania. Annals of the Magazine of Natural History 7: $542-546$.

HIGHSMITH RC (1985) Floating and algal rafting as potential dispersal mechanisms in brooding invertebrates. Marine Ecology Progress Series 25: 169-171.

HOBDAY AJ (2000a) Age of drifting Macrocystis pyrifera (L.) C. Agardh rafts in the Southern California Bight. Journal of Experimental Marine Biology and Ecology 253: 97-114.

HOBDAY AJ (2000b) Persistence and transport of fauna on drifting kelp (Macrocystis pyrifera (L.) C. Agardh) rafts in the Southern California Bight. Journal of Experimental Marine Biology and Ecology 253: 7596.

INGÓLFSSON A (1995) Floating clumps of seaweed around Iceland: natural microcosms and a means of dispersal for shore fauna. Marine Biology 122: 13-21.

JACCARD P (1908) Nouvelles recherches sur la distribution florale. Bulletin Society Sciences Naturale 44: 223-270.

JAKSIC F \& R MEDEL (1987) El acuchillamiento de datos como método de obtención de intervalos de confianza y de prueba de hipótesis para índices ecológicos. Medio Ambiente (Chile) 8: 95-103. 
JARA C \& E JARAMILLO (1979) Hallazgo de Planes marinus Rathbun, 1914, sobre boya a la deriva en Bahia de Maiquillahue, Chile, (Crustacea, Decapoda, Grapsidae). Medio Ambiente (Chile) 4: 108-113.

KRAPP-SCHICKEL T (1993) Suborder Caprellidea. En: Ruffo S (ed) The Amphipoda of the Mediterranean. Mémoires de 1'Institut Oceanographique (Monaco) 13: 773-809.

LANCELLOTTI DA \& RG TRUCCO (1993) Distribution patterns and coexistence of six species of the amphipod genus Hyale. Marine Ecology Progress Series 93: 131-141.

LANCELLOTTI DA \& JA VÁSQUEZ (2000) Zoogeography of benthic macroinvertebrates of the Chilean coast: contribution for marine conservation. Revista Chilena de Historia Natural 73: 99-129.

LARSEN K (1998) Caprellidea (Crustacea: Amphipoda) from Faroe Islands waters, with a key to the NorthAtlantic species. Faroes Journal of Arts and Sciences 46: 81-90.

LAUBITZ DR (1970) Studies on the Caprellidae (Crustacea, Amphipoda) of the American North Pacific. National Museums of Canada, Publications in Biological Oceanography 1: 1-89.

LAUBITZ DR (1972) The Caprellidae (Crustacea, Amphipoda) of Atlantic and Arctic Canada. National Museums of Canada, Publications in Biological Oceanography 4: 1-82.

LIM STA \& CG ALEXANDER (1986) Reproductive behaviour of the caprellid amphipod Caprella scaura typica Mayer, 1890. Marine Behaviour and Physiology 12: 217-230.

LOCKE A \& S COREY (1989) Amphipods, isopods and surface currents: a case for passive dispersal in the Bay of Fundy, Canada. Journal of Plankton Research 11: 419-430.

MALDONADO M \& M URIZ (1995) Biotic affinities in a transitional zone between the Atlantic and the Mediterranean: a biogeographical approach based on sponges. Journal of Biogeography 22: 89-110.

MARQUES JC \& D BELLAN-SANTINI (1985) Contribution à l'étude systématique et écologique des amphipodes (Crustacea-Amphipoda) des côtes de Portugal. Premier inventaire des espèces (Gammariens et Caprelliens). Ciência Biologica 5: 299-353.

MAYER P (1890) Die Caprelliden des Golfes von Neapel und der angrenzenden Meeresabschnitte. Nachtrag zur Monographie derselben. Fauna und Flora des Golfes von Neapel 17: 1-157.

McCAIN JC (1968) The Caprellidae (Crustacea: Amphipoda) of the western North Atlantic. United States National Museum Bulletin 278: 1-147.

McCAIN JC (1969) New Zealand Caprellidea (Crustacea: Amphipoda). New Zealand Journal of Marine and Freshwater Research 3: 286-295.

McCAIN JC \& JE STEINBERG (1970) Amphipoda I. Caprellidea I. Fam. Caprellidae. En: Gruner HE \& LB Holthuis (eds) Crustaceorum Catalogus, Pars 2: 1-78. Dr. W. Junk Publishers, The Hague, The Netherlands.

McCAIN JC \& WS GRAY (1971) Antarctic and Subantarctic Caprellidea (Crustacea: Amphipoda). Antarctic Research Series 17: 111-139.
MOYANO H (1991) Bryozoa marinos Chilenos VIII: una síntesis zoogeográfica con consideraciones sistemáticas y la descripción de diez especies y dos géneros. Gayana Zoología (Chile) 55: 305-389.

NARANJO SA, JL CARBALLO \& JC GARCÍA-GÓMEZ (1996) Effects of environmental stress on ascidian populations in Algeciras Bay (southern Spain). Possible marine bioindicators? Marine Ecology Progress Series 144: 119-131.

OJEDA FP, FA LABRA \& AA MUÑOZ (2000) Biogeographic patterns of Chilean littoral fishes. Revista Chilena de Historia Natural 73: 625-641.

RIVADENEIRA MM，M FERNÁNDEZ \& SA NAVARRETE (2002) Latitudinal trends of species diversity in rocky intertidal herbivore assemblages: spatial scale and the relationship between local and regional species richness. Marine Ecology Progress Series 245: 123-131.

ROY K, D JABLONKSI, JW VALENTINE \& G ROSENBERG (1998) Marine latitudinal diversity gradients: tests of causal hypotheses. Proceedings of the National Academy of Sciences USA 95: 36993702 .

ROY K, D JABLONKSI \& JW VALENTINE (2000) Dissecting latitudinal diversity gradients: functional groups and clades of marine bivalves. Proceedings of the Royal Society of London, Series B 267: 293-299.

SÁNCHEZ-MOYANO JE \& JC GARCÍA-GÓMEZ (1998) The arthropod community, especially crustacea, as bioindicator in Algeciras Bay (Southern Spain) based on a spatial distribution. Journal of Coastal Research 14: $197-204$

SCHELLENBERG A (1935) Gammariden und Caprelliden des Magellangebietes, Südgeorgiens und der Westantarktis. Further Zoological Results of the Swedish Antarctic Expedition 1901-1903, 2: 1-290.

SEREJO CS (1998) Gammaridean and caprellidean fauna (Crustacea) associated with the sponge Dysidea fragilis Johnston at arraial do Cabo, Rio de Janeiro, Brazil. Bulletin of Marine Science 63: 363-385.

SIVAPRAKASAM TE (1977) The skeleton shrimps (Amphipoda: Caprellidea) of the Tamil Nadu and Kerala Coasts. Journal of the Marine Biological Association of India 19: 78-96.

SMITH SDA (2002) Kelp rafts in the southern ocean. Global Ecology and Biogeography 11: 67-69.

SNEATH PHA \& RR SOKAL (1973) Numerical taxonomy: the principles and practise of numerical classification. W.H. Freeman \& Company, San Francisco, California, USA. $573 \mathrm{pp}$.

SORBAZO M (2002) Wind, tides, and circulation in Chilean embayments. In: Castilla JC \& JL Largier (eds) The oceanography and ecology of the nearshore and bays in Chile: 97-113. Ediciones Universidad Católica de Chile, Santiago, Chile.

SWALDON S (1990) Suborder Caprellidea. In: Hayward PJ \& JS Ryland (eds) The marine fauna of the British Isles and north-west Europe. Volume 1, introduction and protozoans to arthropods: 482-488. Clarendon Press, Oxford, United Kingdom.

TAKEUCHI I (1999) Checklist and bibliography of the Caprellidea (Crustacea: Amphipoda) from Japanese waters. Otsuchi Marine Science 24: 5-17. 
TAKEUCHI I \& R HIRANO (1995) Clinging behavior of the epifaunal caprellids (Amphipoda) inhabiting the Sargassum zone on the Pacific coast of Japan, with its evolutionary implications. Journal of Crustacean Biology 15: 481-492.

TAKEUCHI I \& A HINO (1997) Community structure of caprellid amphipods (Crustacea) on Seagrasses in Otsuchi Bay, Northeastern Japan, with Reference to the Association of Caprella japonica (Schurin) and Phyllospadix iwatensis Makino. Fisheries Science 63: 327-331.

TAKEUCHI I \& S SAWAMOTO (1998) Distribution of caprellid amphipods (Crustacea) in the western North Pacific based on the CSK International Zooplankton Collection. Plankton Biology and Ecology 45: 225230.

TAKEUCHI I, R KUWABARA, R HIRANO \& H YAMAKAWA (1987) Species composition of the Caprellidea (Crustacea: Amphipoda) of the Sargassum zone on the pacific coast of Japan. Bulletin of Marine Science 41: 253-267.

Associate Editor: Patricio Camus

Received May 23, 2002; accepted January 13, 2003
TAKEUCHI I, H YAMAKAWA \& M FUJIWARA (1990) The Caprellidea (Crustacea: Amphipoda) inhabiting the green alga Cladophora wrightiana: the influence of wave exposure on the species composition. La mer 28: $139-145$

THIEL M (2002) The zoogeography of algae-associated peracarids along the Pacific coast of Chile. Journal of Biogeography 29: 999-1008.

WATLING L (1996) The Suborder Caprellidea. In: Bake JA, L Watling \& PH Scott (eds) Taxonomic atlas of the benthic fauna of the Santa Maria Basin and western Santa Barbara Channel. Volume 12. The Crustacea Part 3. The Amphipoda: 223-240. Santa Barbara Museum of Natural History, Santa Barbara, California, USA.

WAKABARA Y, AS TARARAM, MS VALÉRIOBERARDO, W DULEBA \& FP LEITE (1991) Gammaridean and caprellidean fauna from Brazil. Hydrobiologia 223: 69-77. 


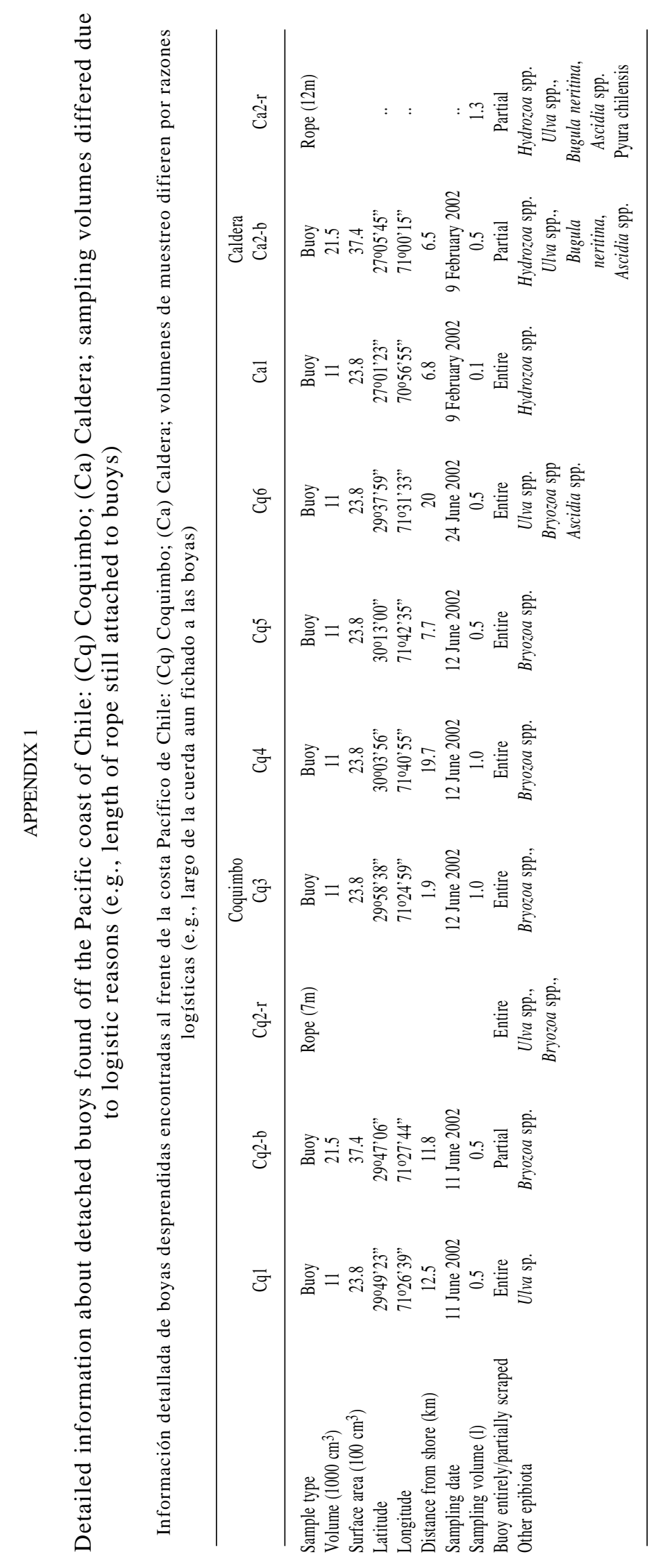

